\title{
THE DISTINCTION OF FIVE MALLOTUS SPECIES FORMERLY IN SECTION HANCEA (EUPHORBIACEAE)
}

\author{
P.C. VAN WELZEN, S.E.C. SIERRA, M.J.H. GEBRAAD \& K.K.M. KULJU \\ Nationaal Herbarium Nederland, Universiteit Leiden branch, \\ P.O. Box 9514, 2300 RA Leiden, The Netherlands; \\ e-mail:welzen@nhn.leidenuniv.nl; sierra@nhn.leidenuniv.nl; kulju@nhn.leidenuniv.nl
}

\begin{abstract}
SUMMARY
Mallotus concinnus Airy Shaw, M. havilandii Airy Shaw, M. insularum (Airy Shaw) Slik, and M. miquelianus (Scheff.) Boerl. are very similar in appearance, with opposite leaves of which one large and elliptic, and the other reduced and more or less obcordate. However, a detailed look revealed enough differences to regard them as distinct species.
\end{abstract}

Key words: Euphorbiaceae, Hancea, Mallotus.

\section{INTRODUCTION}

Mallotus Lour. is one of the larger genera in the Euphorbiaceae with c. 150 species, which are mainly found in Southeast Asia and the Malay Archipelago, but there are also some species in Africa and the Indian Ocean. The genus is divided into several sections of which some are distinct, but others appear to be poly- or paraphyletic (e.g., Slik \& Van Welzen, 2001a). One well-defined section is Hancea. This group of species has opposite leaves of which one is reduced and stipule-like. This section only became really distinct after several species were excluded (Slik \& Van Welzen, 2001b).

Recent morphological studies (Sierra, pers. comm.) and phylogenetic analyses based on sequence data (Kulju, pers. comm.) show that section Hancea and the monotypic section Oliganthae (M. subpeltatus (Blume) Müll.Arg.) are not closely related to Mallotus and they will be united with another genus in a forthcoming paper (Sierra et al., ms.). Hancea s.s. and Oliganthae lack typical Mallotus characters like glandular scales (more or less sessile, flat, glandular hairs), stellate hairs, and extrafloral nectaries on the leaf blades. On the other hand, they show club-shaped glandular hairs (sometimes minute but always stalked and globular; absent in Mallotus s. s.) and a single staminate flower per bract instead of several as in Mallotus s.s. (this is contrary to Slik \& Van Welzen, 2001b, who still note 1-6 flowers per bract). The excluded species show the typical Mallotus s. s. characters and lack those of section Hancea (except for M. brachythyrsus Merr., see below).

In this paper we will discuss the species excluded from section Hancea. Slik \& Van Welzen (2001b) indicated that they have to be included in the sections Axenfeldia and/or Rottleropsis. Both sections also have opposite leaves, mainly pinnate-nerved in Axenfeldia and triplinerved in Rottleropsis. This difference in venation shows overlap and 


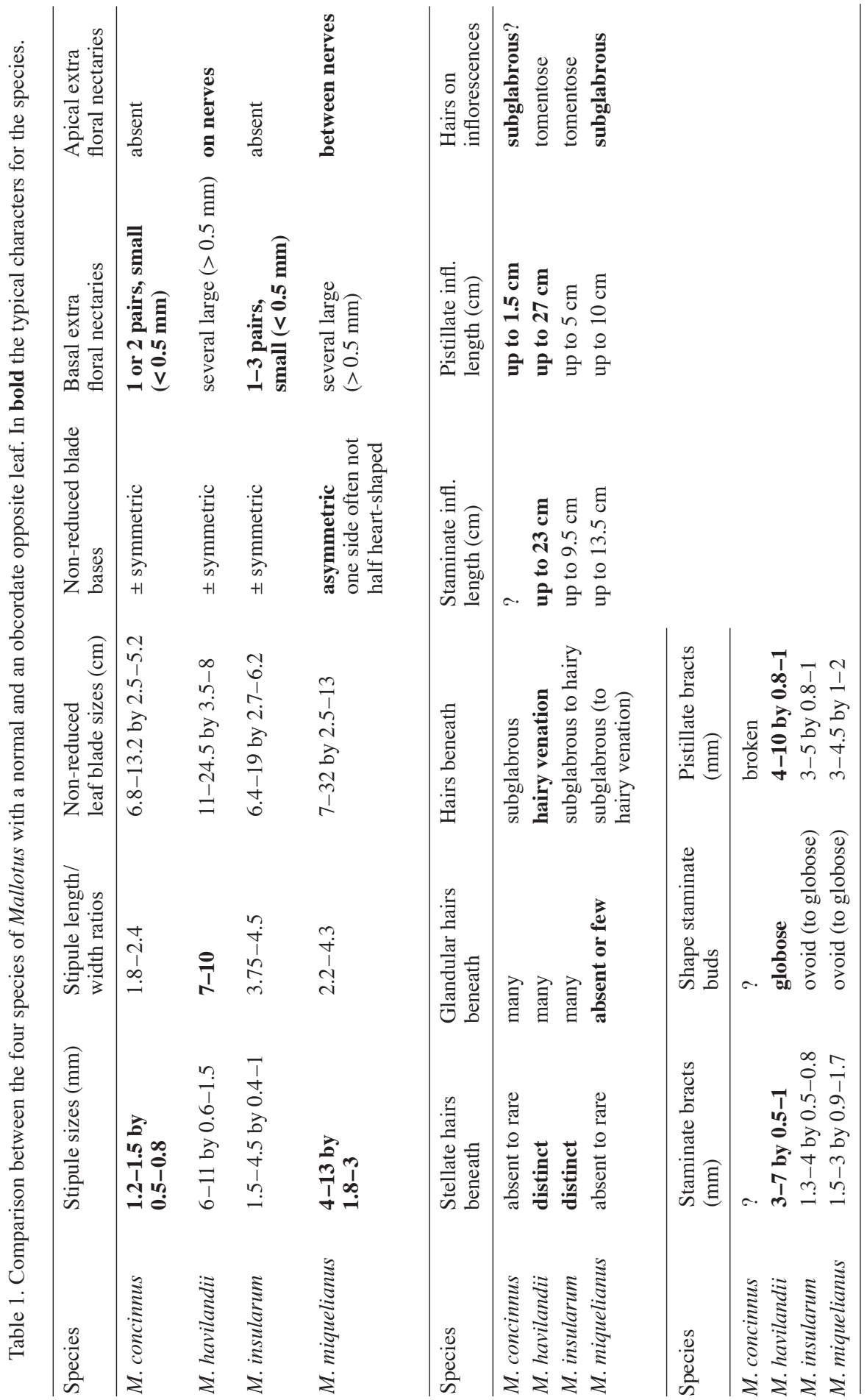


phylogenetic analyses demonstrate both sections to be polyphyletic (Slik \& Van Welzen, 2001a; Kulju, pers. comm.) or paraphyletic when united. The exact sectional division of Mallotus s.s. is still far from finished. The opposite leaves of Axenfeldia and Rottleropsis are similar in shape, but one is generally (much) smaller. The excluded species differ in this respect, they have leaf pairs which differ in shape, one is generally elliptic, the other stipule-like or more or less obcordate. The excluded species are: M. brachythyrsus, $M$. concinnus, $M$. havilandii, $M$. insularum, and $M$. miquelianus. Of these species, M. brachythyrsus resembles section Hancea the most: stipule-like leaves and a single staminate flower per bract (but with stellate hairs, extrafloral nectaries, and glandular scales like Mallotus s. s.). Phylogenies based on molecular data show M. brachythyrsus to be close to M. miquelianus and both are part of Mallotus s.s. (Kulju, pers. comm.). Thus, the character states stipule-like leaves and single staminate flowers in M. brachythyrsus are parallel developments with section Hancea. The other four species look quite alike and are usually referred to M. miquelianus, the most widespread species, ranging from Thailand to Borneo and the Philippines (map 9 in Slik \& Van Welzen, 2001b). Mallotus havilandii is endemic on limestone close to Kuching, Sarawak (map 8 in Slik \& Van Welzen, 2001b). Mallotus insularum, formerly a variety of M. miquelianus, is present in the Moluccas and the Lesser Sunda Islands (map 8 in Slik \& Van Welzen, 2001b, omit Flores, see below).

Recently we came across the name Mallotus concinnus, also a limestone species, present in Kelantan, Peninsular Malaysia. When interpreting M. concinnus we first thought it to be a synonym of $M$. miquelianus, but synonymising this name with M. miquelianus would have a 'domino effect', other names, especially $M$. insularum, would then have to be synonymised too. Moreover, Slik \& Van Welzen (2001b) do not indicate the differences between $M$. havilandii, M. insularum, and M. miquelianus. According to Slik (pers. comm.) it is unclear that M. concinnus and M. insularum can be separated. A careful comparison showed all four species to be distinct, but several specimens appeared to be wrongly identified, mainly as $M$. miquelianus. These are compelling reasons to write this article and to clarify the differences between the species.

\section{COMPARISON}

Table 1 summarises the differences among the four species (the very distinct M. brachythyrsus is not included, see above). Mallotus miquelianus, the most widespread and most variable species, is easy to distinguish vegetatively. It is the only species with a very distinctly oblique base of the leaf blade, with often one side half heart-shaped and the other almost cuneate. Only one exception was found, Soejarto et al. 8750 has a symmetric leaf base. Other leaf characters are the (almost complete) absence of stellate and glandular scales on the lower surface and the presence of apical extrafloral nectaries between the nerves (secondary veins) on the upper surface.

Also relatively well recognisable is Mallotus havilandii, with long and slender stipules (those of M. miquelianus are also long, but relatively broad) and the presence of apical extrafloral nectaries on the nerves on the upper surface (thus not between the nerves as in M. miquelianus). The stellate hairs are distinct. Most typical are the hairy and long inflorescences with very long staminate or pistillate bracts. The staminate 
buds are globose instead of ovoid. The base of the leaf blade is symmetric in the sense that both sides are half heart-shaped, the base may be slightly oblique as meant in Slik \& Van Welzen (2001b).

Mallotus concinnus and M. insularum (from West and East Malesia, respectively) show an extreme resemblance. A problem is that the flowers and fruits of M. concinnus are virtually unknown. Vegetatively the best character is the (near) absence of stellate hairs on the lower leaf blade surface in $M$. concinnus and the shorter stipules of this species.

Of Mallotus insularum only four specimens are known with a very disjunct distribution, two specimens are from the Sulu Archipelago, islands between Sulawesi and the Moluccas (Bloembergen 4482 and Buwalda 4575), and two specimens are from the Lesser Sunda Islands, present on the islands Bali (W. Meijer 10611) and Lombok (Elbert 2495) (Slik \& Van Welzen, 2001b, tentatively added two specimens from Flores, Schmutz 2860 and Schmutz 3160, but these specimens are not M. insularum). The specimens from the Lesser Sunda Islands have somewhat larger leaves $(8-19 \mathrm{~cm}$ long; NB: different from the description in Slik \& Van Welzen, 2001b, due to exclusion of the Flores specimens) and larger stipules than the Moluccan specimens (leaves $6.5-13 \mathrm{~cm}$ long), but no other distinctive characters appear to be present. Therefore, due to lack of more specimens these entities are regarded as a single species.

Although three of the four species are already described (Slik \& Van Welzen, 2001b) a key to them is still missing:

\section{KEY TO THE SPECIES WITH AN OPPOSITE OBCORDATE LEAF}

1a. Leaf base symmetric to slightly oblique, emarginate. Lower leaf blade surface with many glandular hairs, often also stellate hairs. Apical extrafloral nectaries on upper leaf blade surface absent or on the nerves (secondary veins) . . . . . . . . 2

b. Leaf base oblique, asymmetric with one side half heart-shaped, the other almost cuneate. Lower leaf blade surface without or with very few glandular hairs, very seldomly a few stellate hairs. Apical extrafloral nectaries on upper leaf blade surface

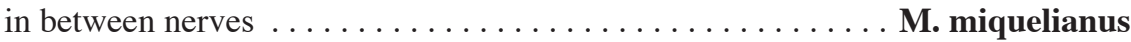
(see Slik \& Van Welzen, 2001b: 56, f. 22, map 9)

2a. Stipules 1.2-4.5 mm long, 1.8-4.5 times as long as broad. Apical extrafloral nectaries on upper blade surface absent (only basal ones present). Staminate inflorescences up to $9.5 \mathrm{~cm}$ long; staminate bracts $1.3-4 \mathrm{~mm}$ long (unknown for M. concinnus); pistillate bracts in M. insularum 3-5 mm long (broken, but small in M. concinnus).

- Peninsular Malaysia or Moluccas and Lesser Sunda Islands . . . . . . . . . . 3

b. Stipules 6-11 mm long, 7-10 times as long as broad. Apical extrafloral nectaries on upper leaf blade surface on the nerves (secondary veins). Staminate inflorescences up to $23 \mathrm{~cm}$ long; staminate bracts 3-7 mm long, pistillate bracts 4-10 $\mathrm{mm}$ long. - Borneo (Sarawak: near Kuching) . . . . . . . . . . . . M. havilandii (see Slik \& Van Welzen, 2001b: 52, f. 20, map 8)

3a. Stipules $1.2-1.5 \mathrm{~mm}$ long. Lower blade surface with simple hairs only. - Penin-

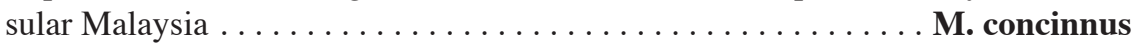


b. Stipules $1.5-4.5 \mathrm{~mm}$ long. Lower blade surface with many stellate hairs. - Moluccas (Sulu Archipelago), Lesser Sunda Islands (Bali, Lombok). . . M. insularum (see Slik \& Van Welzen, 2001b: 54, f. 21, map 8)

\section{DESCRIPTION OF MALLOTUS CONCINNUS}

The other three species are described in Slik \& Van Welzen (2001b).

\section{Mallotus concinnus Airy Shaw}

Mallotus concinnus Airy Shaw (1978) 406. - ?Erismanthus sp.: M.R. Hend. (1939) 70. - Type: Henderson SF 19543 (holo K; iso K, SING), Malaya, Kelantan, Gua Panjang, Gua Ninik.

Shrub, up to $3 \mathrm{~m}$ tall; branchlets terete, up to $3 \mathrm{~mm}$ thick. Indumentum sparse, very short simple or stellately bundled hairs and yellowish glandular scales. Stipules early caducous, triangular, $1.2-1.5$ by $0.5-0.8 \mathrm{~mm}$, margin entire, apex acute, outside with simple hairs. Leaves simple, opposite, unequal, one much smaller and often caducous. Non-reduced leaves: petiole 1-4 mm long, with simple hairs; blade elliptic to obovate, $6.8-13.2$ by $2.5-5.2 \mathrm{~cm}$, length/width ratio $2.5-2.7$, pergamentaceous, symmetric, drying greenish or brownish, base cordate, symmetric, margin coarsely serrate to subserrate, teeth ending in glands, apex cuspidate to caudate, upper surface with basally a single or two pairs of small extrafloral nectaries on the basal nerves, glabrous, lower surface with simple hairs on the midrib and nerves, many glandular hairs and hair tuft domatia present; nerves 7-9 per side, arching, looped and closed near margin, venation especially raised beneath. Reduced leaves subsessile, obcordate to reniform, 4-11 by 4-12 mm, margin laxly dentate, apex rounded to acute, upper surface without extrafloral nectaries, lower surface with glandular hairs; venation distinct on both sides. Staminate inflorescences and flowers unknown. Pistillate inflorescences single, axillary, up to 1.5 $\mathrm{cm}$ long, few-flowered, not densely hairy with simple hairs and glandular hairs; bracts broad and short, broken. Pistillate flowers c. $1.75 \mathrm{~mm}$ in diameter, white; pedicel 1-2 mm long, puberulous; sepals 4 (single badly preserved flower seen), ovate, c. 1.8 by $1.2 \mathrm{~mm}$, revolute, glandular hairs inside and outside, outside laxly puberulous; ovary 3-locular, muricate, with a few short hairs and many glandular hairs; stigmas c. 2.5 mm long, plumose-papillate above. Fruits capsular, red (label information), not seen; column 4-5 mm long. Seeds not seen.

Distribution - Peninsular Malaysia: Kelantan.

Habitat \& Ecology - On dry rocky summit in scrubby vegetation with wet humus and a dense ground cover of mainly orchids and ferns; soil: limestone. At 300-500 m altitude.

Specimens examined:

Chin 1552, Gua Musang; Henderson SF 19543, Gua Panjang.

\section{ACKNOWLEDGEMENTS}

The directors and keepers of K, L, and SING are thanked for sending material on loan or for allowing us to visit them. Ferry Slik, Živa Fišer, and two referees are thanked for their useful comments. 


\section{REFERENCES}

Airy Shaw, H.K. 1978. Notes on Malesian and other Asiatic Euphorbiaceae. CXCIX. New or noteworthy species of Mallotus Lour. Kew Bull. 32: 400-407.

Henderson, M.R. 1939. The flora of the limestone hills of the Malay Peninsula. J. Malayan Branch Roy. Asiat. Soc. 17: 13-87.

Slik, J.W.F. \& P.C. van Welzen. 2001a. A phylogeny of Mallotus (Euphorbiaceae) based on morphology: Indications for a pioneer origin of Macaranga. Syst. Bot. 26: 786-796.

Slik, J.W.F. \& P.C. van Welzen. 2001b. A taxonomic revision of Mallotus sections Hancea and Stylanthus (Euphorbiaceae). Blumea 46: 3-66. 